\title{
PROPORSI BANGSA, UMUR, BOBOT BADAN AWAL DAN SKOR KONDISI TUBUH SAPI BAKALAN PADA USAHA PENGGEMUKAN
}

\section{PROPORTION OF BREED, AGES, INITIAL BODY WEIGHT AND BODY CONDITION SCORE OF CATTLE IN FEEDLOT}

\author{
Frandz Rumbiak Pawere ${ }^{1 *}$, Endang Baliarti ${ }^{2}$, dan Sudi Nurtini ${ }^{2}$ \\ ${ }^{1}$ Fakultas Peternakan Perikanan dan Ilmu Kelautan, Universitas Negeri Papua, Jl. Gunung Salju, Amban, Manokwari, \\ Propinsi Papua Barat \\ ${ }^{2}$ Fakultas Peternakan, Universitas Gadjah Mada, Jl. Fauna No. 3, Bulaksumur, Yogyakarta, 55281
}

\section{INTISARI}

Penelitian ini bertujuan untuk mengetahui proporsi bangsa, umur, skor kondisi tubuh sapi bakalan yang digemukkan pada usaha penggemukan. Penelitian dilaksanakan di CV. Restu Bumi, Kabupaten Bantul selama 1 tahun yakni dari bulan Mei 2011 sampai bulan Mei 2012. Materi yang digunakan adalah 500 ekor sapi meliputi bangsa sapi Limmousin Peranakan Ongole (LimPO), Peranakan Ongole (PO) dan Simmental Peranakan Ongole (SimPO). Parameter yang diamati adalah bangsa, umur, body condition score (BCS). Metode analisis yang digunakan adalah analisis deskriptif. Hasil penelitian menunjukkan bahwa proporsi bangsa sapi yang digemukkan-SimPO (56\%), LimPO (19\%) dan PO (25\%), umur sapi yang paling banyak digemukkan adalah poel 1 dan poel 2 masing-masing $36 \%$ dan $25 \%$. Bobot badan awal sapi $<300 \mathrm{~kg}$ didominasi oleh bangsa sapi PO dan bobot badan awal $>300 \mathrm{~kg}$ didominasi oleh bangsa sapi silangan (SimPO dan LimPO). Nilai body condition score (BCS) awal penggemukan 2-3.

(Kata kunci: Bangsa, LimPO, PO, SimPO, Penggemukan)

\section{ABSTRACT}

The purposed of this study was to identify the proportion of breed, ages, body condition score (BCS) of cattle which were fed in feedlot. This research was carried out at CV. Restu Bumi, Bantul regency from May 2011 to May 2012. Five hundreds cattle were used in this experiments, consisted of three breeds LimPO, PO and SimPO. Data collected were breeds, ages, and BCS. Method of analysis used was descriptive analyses. The result of the study showed that the proportion of SimPO breed was the biggest percentage (56\%) followed by PO (25\%) and LimPO (19\%). The preferred ages of cattle to be fattened were cattle which had first permanent incisors ( $t w o-y e a r$ old cattle). Initial body weight of cattle $<300 \mathrm{~kg}$ were dominated by PO breed and initial body weight of cattle $>300 \mathrm{~kg}$ were dominated by crossbreed (SimPO and LimPO). BCS value of cattle before feedlot was 2-3.

(Keywords: Breed, LimPO, PO, SimPO, Feedlot)

\section{Pendahuluan}

Permintaan daging yang tinggi menyebabkan masyarakat memilih usaha penggemukan. Impor sapi ke Indonesia tahun 2012 terdiri atas 34.000 ton (40\%) daging beku dan sapi bakalan 51.000 ton $(60 \%)$. Tingginya permintaan akan daging mendorong CV. Restu Bumi untuk menjual ternaknya. Penjualan dan pembelian ternak di Daerah Istimewa Yogyakarta biasanya dilakukan di pasar hewan Siyonoharjo, Imogiri, Gamping (Ambarketawang) dan Prambanan. Namun ternak yang mau dijual biasanya ternak yang kurus, tua, dan tidak produktif lagi sehingga terjual dengan harga yang kurang

\footnotetext{
* Korespondensi (corresponding author):

Telp. +62 81338508443

E-mail: frandz_pawere@yahoo.co.id
}

pantas. Akibatnya CV. Restu Bumi yang memilih menggemukkan sapi terlebih dahulu sebelum dijual agar memperoleh harga yang pantas. Proporsi pembelian sapi bakalan di pasar hewan sampai saat ini belum pernah dikaji padahal informasi ini sangat penting bagi pemerintah sebagai bahan pertimbangan dalam merumuskan program peningkatan produktivitas sapi potong di Indonesia.

Bangsa sapi yang baik untuk digemukkan adalah bangsa sapi campuran keturunan pertama (F1) yakni sapi hasil persilangan sapi lokal dengan sapi impor (Santosa, 2001; Trifena et al., 2011). Umumnya bangsa sapi hasil persilangan keturunan pertama (crossbreed) lebih bagus dibanding bangsa sapi lokal karena memilki performans produksi lebih baik (Musthafa, 2011) dan konsumsi bahan kering, bahan organik, protein kasar dan total 
digestible nutrients pada induk sapi SimPO dengan pakan hijauan dan konsentrat lebih tinggi daripada induk sapi PO (Endrawati et al., 2010). Namun data tentang proporsi bangsa sapi crossbreed maupun sapi lokal yang digemukkan sampai sekarang belum diketahui secara kuantitatif.

Secara teoritis umur sapi bakalan yang baik untuk digemukkan adalah 1,5-2,5 tahun atau gigi seri tetap sudah 1-2 pasang (poel 1 dan 2) karena umumnya sapi bakalan yang berumur demikian memiliki laju pertumbuhan yang optimal, efisiensi pakan yang tinggi (Ngadiyono, 2007). Data riil di lapangan tentang umur sapi bakalan yang digemukkan belum pernah dikaji secara ilmiah padahal informasi ini sangat bermanfaat bagi pihak pemerintah maupun stakeholder dan CV. Restu Bumi, sehingga perlu pengkajian lebih lanjut.

Body condition score $(B C S)$ atau skor kondisi tubuh sapi sangat mempengaruhi keberhasilan usaha penggemukan. Menurut OFAC (2010), sapi bakalan yang baik untuk digemukkan adalah sapi dengan nilai BCS 2,5 (kurus) - 3 (sedang). Selama ini belum ada penelitian yang melihat perbedaan BCS antara bangsa sapi yang digemukkan pada usaha penggemukan, oleh karena itu perlu ada kajian ilmiah.

Tujuan dari penelitian ini adalah untuk mengetahui proporsi bangsa, umur, dan BCS sapi bakalan yang digemukkan. Informasi tentang bangsa, umur, dan BCS sapi bakalan yang paling disukai CV. Restu Bumi sangat berguna bagi pemerintah, stakeholder dan CV. Restu Bumi sebagai bahan pertimbangan dalam merumuskan program pengembangan produktivitas ternak sapi potong di Indonesia.

\section{Materi dan Metode}

Penelitian dilaksanakan di CV. Restu Bumi, Dusun Segoroyoso, Kecamatan Pleret, Kabupaten Bantul selama 1 tahun yakni bulan Mei 2011 sampai bulan Mei 2012.

Materi yang digunakan dalam penelitian ini adalah 500 ekor sapi yang dibeli dan digemukkan selama kurun waktu penelitian.

Peralatan yang digunakan adalah kandang individu sebanyak 100 petak dengan ukuran masing-masing $1,5 \times 2,5 \mathrm{~m}$ yang dilengkapi tempat pakan dan air minum yang terpisah. Peralatan lain adalah timbangan ternak merek FHK kapasitas 1200 kg dengan kepekaan $1 \mathrm{~kg}$, ember 100 buah, sekop, mesin cacah untuk mencacah ketela.

Penelitian ini menggunakan metode observasi langsung (direct observation) dengan menggunakan pedoman observasi berisi daftar kegiatan yang akan dicatat. Daftar kegiatan berupa tanggal beli, harga beli, bangsa, jenis kelamin, poel gigi, bobot badan awal, dan skor kondisi tubuh sapi bakalan.

Penelitian berlangsung selama 1 tahun. Selama waktu ini setiap ada pembelian ternak dicatat tanggal beli, harga belinya, kemudian ditimbang bobot badan awal, dipasang nomor ternak yang terbuat dari plastik, dicatat bangsa, jenis kelamin, poel gigi, skor kondisi tubuh.

Data yang dikumpulkan meliputi tanggal pembelian, asal ternak, jenis kelamin, bangsa sapi, poel gigi, bobot badan awal, BCS awal. Penilaian BCS dilakukan dengan berdiri di belakang, samping kanan dan kiri sapi untuk menilai tulang ekor dan pinggang dengan mengendalikan sapi secara tenang dan berhati-hati menggunakan tangan yang sama. Tulang ekor dinilai dengan perasaan untuk memprediksi jumlah lemak di sekitar tulang. Penentuan BCS berdasarkan aturan Affandhy et al. (2001).

Data yang diperoleh dianalisis secara deskriptif. Data tentang bangsa sapi dianalisis untuk mengetahui proporsi masing-masing bangsa sapi. Data tentang umur dianalisis untuk mengetahui proporsi umur sapi yang dipilih CV. Restu Bumi untuk digemukkan. Data tentang bobot badan awal dianalisis untuk mengetahui proporsi bobot badan awal. Data tentang skor kondisi tubuh dianalisis untuk mengetahui proporsi skor kondisi tubuh.

\section{Hasil dan Pembahasan}

\section{Asal ternak}

Hasil penelitian selama satu tahun tentang proporsi pembelian sapi bakalan di pasar hewan Imogiri, Siyonoharjo, Prambanan dan Gamping disajikan pada Gambar 1.

Gambar 1 menunjukkan CV. Restu Bumi lebih sering membeli sapi bakalan di pasar hewan Imogiri dan Siyonoharjo. Hal ini dikarenakan harga sapi di kedua pasar hewan tersebut murah dibandingkan dengan pasar hewan Gamping dan Prambanan. Selain itu ketersediaan sapi di pasar hewan Siyonoharjo dan Imogiri lebih banyak dibanding pasar hewan lainnya. Alasan lain adalah CV. Restu Bumi lebih banyak mendapatkan sapi yang sesuai keinginannya di kedua pasar hewan tersebut dan juga dapat membeli dalam jumlah yang banyak. Dibanding pasar hewan yang lain, jumlah pembelian sapi di pasar hewan Imogiri lebih banyak yakni 216 ekor (43\%), Siyonoharjo 199 ekor (40\%), Prambanan 45 ekor (9\%), Gamping 40 ekor (8\%) disebabkan oleh biaya transportasi paling murah dibanding pasar hewan lainnya karena letak pasar 


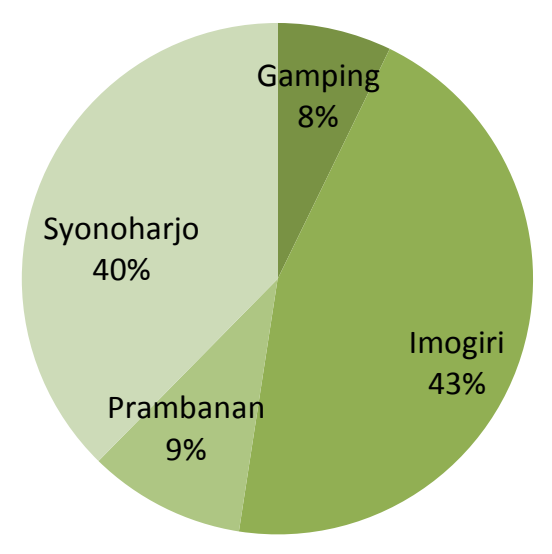

Gambar 1. Diagram proporsi pembelian sapi di pasar hewan (diagram of purchasing cattle proportion at animal market).

hewan Imogori yang berjarak lebih dekat dengan tempat usaha penggemukan CV. Restu Bumi.

\section{Bangsa sapi yang digemukkan}

Hasil penelitian menunjukkan bahwa bangsa sapi SimPO yang paling banyak diminati CV. Restu Bumi yaitu sekitar $56 \%$ diikuti oleh PO $25 \%$ dan LimPO 19\%. Informasi mengenai proporsi bangsa sapi yang digemukkan tersaji pada Gambar 2 .

Hasil penelitian menunjukkan bahwa bangsa sapi SimPO yang paling banyak diminati untuk digemukkan. Hal ini diduga karena sapi SimPO paling banyak dijual di pasar hewan dan harganya yang lebih murah dibandingkan dengan harga sapi LimPO dan PO. Dugaan ini didukung oleh hasil penelitian Sumadi et al. (2008) yang melaporkan bahwa populasi sapi SimPO di pulau Jawa tertinggi sekitar 52,38\% sedangkan populasi sapi PO dan LimPO masing-masing sebesar 25,75 dan 21,87\%. Widianingtyas (2007) melaporkan bahwa populasi sapi hasil silangan di Kecamatan Sentolo Kabupaten Kulon Progo Yogyakarta mencapai persentase tertinggi $(68,26 \%)$ dibanding sapi PO $(31,74 \%)$. Widi et al. (2008) melaporkan bahwa penggunaan semen pejantan Simmental paling disukai di kalangan peternak di Kabupaten Gunungkidul. Selain itu sapi SimPO juga memiliki persentase karkas yang lebih tinggi dan memiliki feed cost per gain yang lebih rendah jika dibandingkan dengan sapi PO dan sapi Limousin (Carvalho et al., 2010; Yulianto dan Cahyo, 2010). Dewi (2005) menyatakan bahwa sapi SimPO menjadi primadona karena mempunyai pertumbuhan yang lebih cepat dan pedet yang dilahirkan memiliki bobot badan yang besar serta memiliki daya jual yang tinggi. Bobot lahir sapi persilangan SimPO adalah tertinggi $(31,1 \mathrm{~kg})$ disusul Charolais dengan PO $(27,5 \mathrm{~kg})$,
Limousin dengan PO $(25,6 \mathrm{~kg})$ dan Brahman dengan PO (24,5 kg) (Thalib et al., 1999).

\section{Proporsi umur sapi}

Umur sapi yang digemukkan pada usaha penggemukan CV. Restu Bumi bervariasi dari sapi yang memiliki gigi poel 1 hingga poel 4 . Hasil penelitian menunjukkan proporsi rata-rata umur sapi berdasarkan poel gigi (Gambar 3).

Gambar 3 menunjukkan bahwa proporsi umur sapi bakalan dengan poel 1 tertinggi sebesar $36 \%$ diikuti berturut-turut oleh sapi dengan poel gigi 2, dan 3 masing-masing 25\% dan 23\%. Dapat dikatakan bahwa CV. Restu Bumi dalam pemilihan sapi bakalan berdasarkan umur, sudah sangat baik karena sapi dengan gigi poel 1 memiliki pertumbuhan yang cepat dan akan memberikan dampak yang lebih ekonomis yang berpengaruh pada pendapatan (Ngadiyono 2007; Rianto dan Purbowati, 2010). Distribusi umur sapi berdasarkan kriteria bangsa sapi disajikan pada Gambar 4.

Gambar 4 memperlihatkan bahwa ketiga bangsa sapi paling banyak digemukkan adalah berumur poel 1 kemudian diikuti berturut-turut poel 2, poel 3, poel 4 dan gigi susu. Secara keseluruhan pada umur poel 1 proporsi sapi SimPO dan LimPO lebih tinggi dari proporsi bangsa sapi PO. Hal ini diduga karena perbedaan bangsa. Sapi SimPO dan LimPO merupakan keturunan bangsa sapi Eropa yang umumnya mempunyai bobot badan yang lebih berat dari sapi PO dan mampu beradaptasi dengan iklim, sedangkan bangsa sapi PO merupakan bangsa sapi lokal yang secara genetik, memiliki bobot badan rendah bila dibandingkan dengan sapi SimPO dan LimPO pada umur yang sama. Pemilihan sapi bakalan pada umur yang masih mengalami pertumbuhan yang cepat akan memberikan dampak yang lebih ekonomis (Rianto dan Purbowati, 2010). 


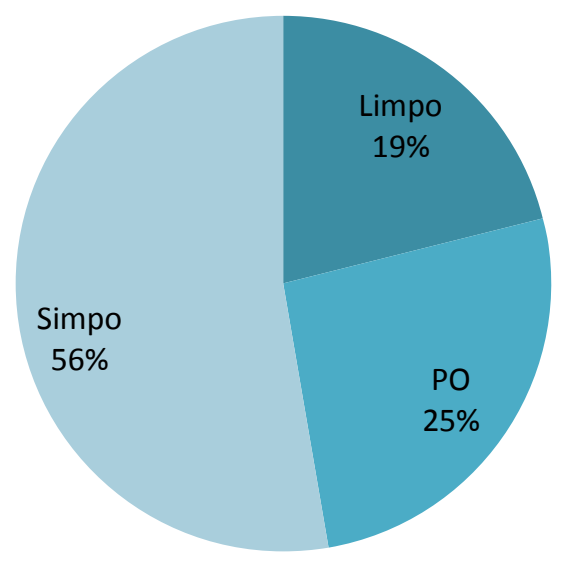

Gambar 2. Diagram proporsi bangsa sapi yang digemukkan (diagram proportion of cattles traits which are fed).

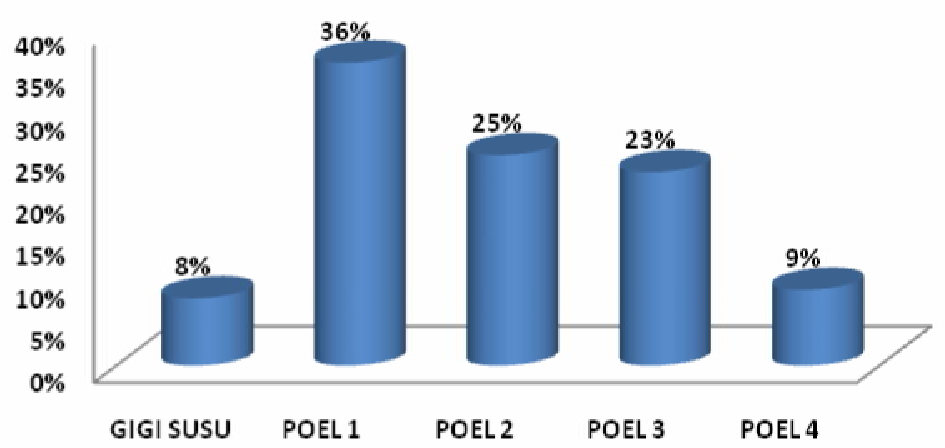

Gambar 3. Proporsi umur sapi yang digemukkan (the ages proportion of cattle which were fed in feedlot).

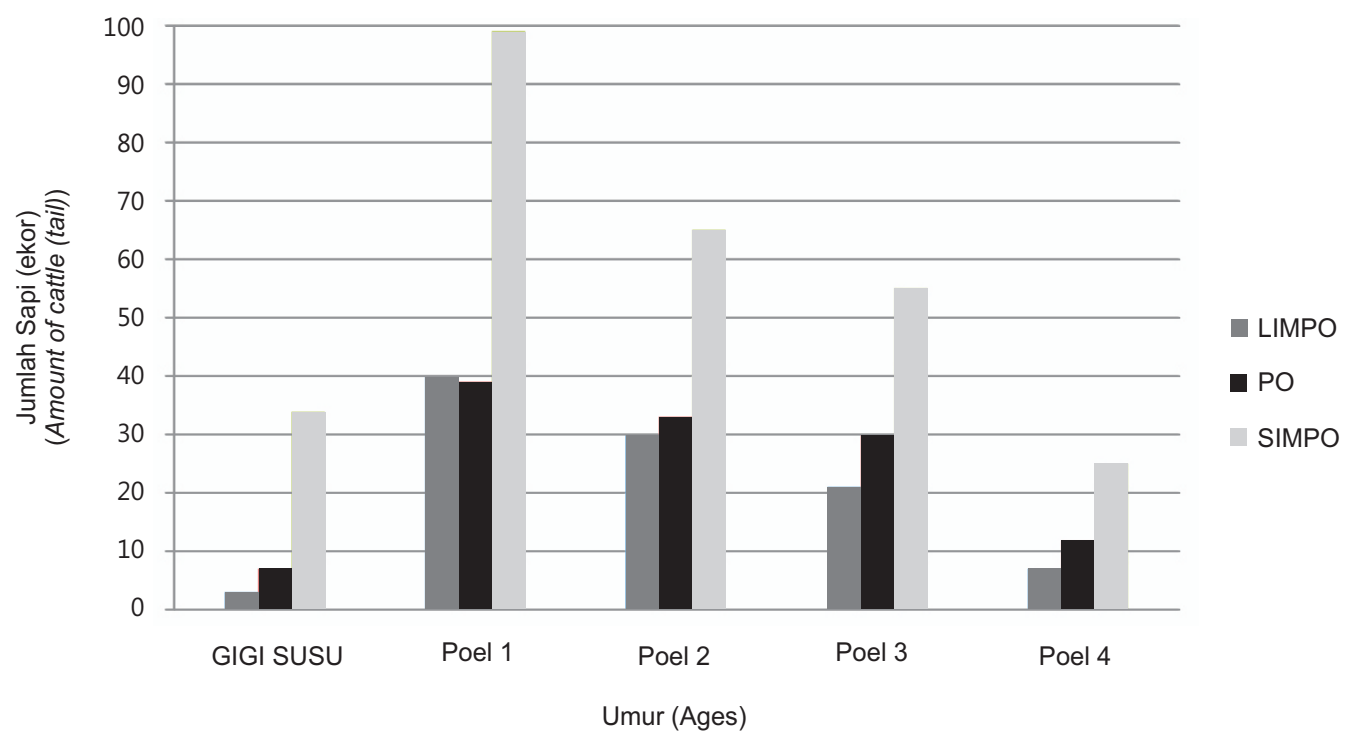

Gambar 4. Umur sapi bakalan berdasarkan bangsa (the ages of cattle base on breed).

\section{Bobot badan awal sapi yang digemukkan}

Sapi yang digemukkan di CV. Restu Bumi memiliki bobot badan awal yang bervariasi sebagaimana disajikan pada Tabel proporsi bobot badan awal sapi bakalan. Tabel tersebut memperlihatkan bahwa kategori bobot badan awal $<300$ didominasi oleh bangsa sapi PO, sedangkan kategori bobot badan awal $>300 \mathrm{~kg}$ didominasi oleh bangsa sapi persilangan. Hal ini diduga karena perbedaan bangsa. Sapi PO merupakan bangsa sapi dari daerah tropis yang secara genetik bobot badan awal lebih kecil dibanding sapi SimPO dan LimPO pada umur yang sama. Tabel tersebut juga memperlihatkan bahwa sebanyak $391 \quad(60 \%)$ ekor sapi yang 
Tabel proporsi bobot badan awal sapi bakalan (the proportion of initial body weight of cattle)

\begin{tabular}{ccccc}
\hline \hline \multirow{2}{*}{ Bangsa (breed) } & \multirow{2}{*}{ Jenis kelamin (sex) } & \multicolumn{3}{c}{ Bobot badan (body weight) } \\
\cline { 3 - 5 } & Jantan (ekor) (male (head) $)$ & 9 & $>300 \mathrm{~kg}$ & Total \\
\hline LimPO & Betina (ekor) (female (head) $)$ & 0 & 66 & 75 \\
& Jantan (ekor) (male (head) & 26 & 22 & 22 \\
PO & Betina (ekor) (female (head)) & 25 & 49 & 54 \\
& Jantan (ekor) (male (head)) & 40 & 159 & 74 \\
SimPO & Betina (ekor) (female (head) & 9 & 67 & 799 \\
& & 109 & 391 & 500 \\
\hline
\end{tabular}

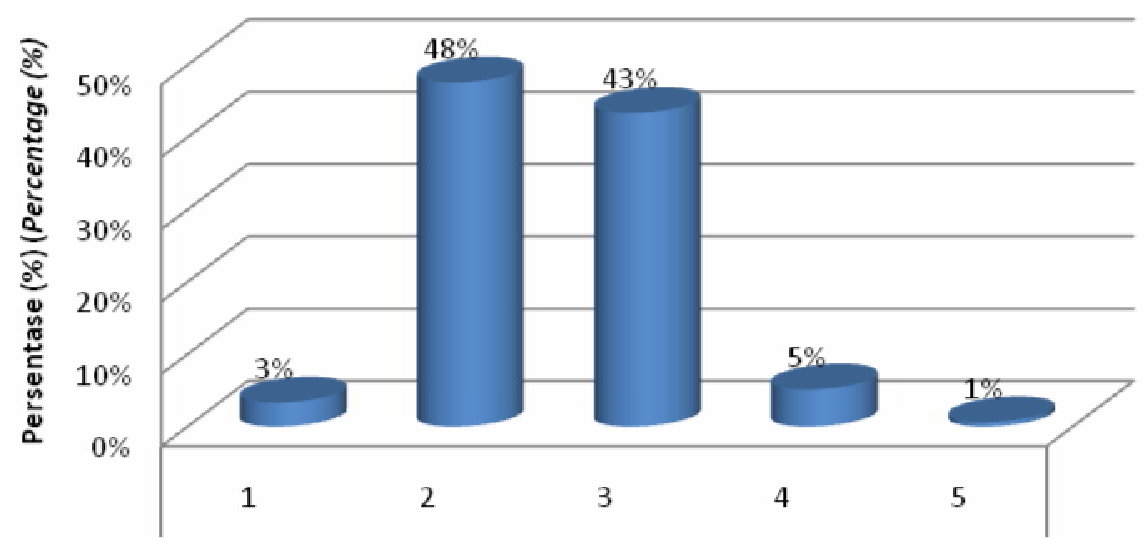

Gambar 5. Skor kondisi tubuh sapi bakalan (body condition score of cattle).

digemukkan memiliki rata-rata bobot badan lebih dari $300 \mathrm{~kg}$ dan 109 ekor (40\%) sapi dengan bobot badan awal kurang dari $300 \mathrm{~kg}$. Menurut CV. Restu Bumi, sapi dengan bobot badan awal $300 \mathrm{~kg}$ lebih efisien dan ekonomis dalam konsumsi pakan dibandingkan sapi dengan bobot badan kurang dari $300 \mathrm{~kg}$.

\section{Skor kondisi tubuh sapi bakalan}

Skor kondisi tubuh sapi bakalan di lokasi penelitian disajikan pada Gambar 5. Gambar 5 menunjukkan proporsi BCS 2 sekitar 48\%, BCS 3 sekitar 43\%, BCS 4 sekitar 5\%, BCS 1 (3\%) dan BCS 5 (1\%). Sapi bakalan dengan BCS 2 atau 3 yang paling banyak digemukkan. Hasil ini sesuai dengan pendapat Ngadiyono (2007) menyatakan bahwa BCS sapi yang baik untuk digemukkan adalah berkisar 2-3.

\section{Kesimpulan}

Berdasarkan hasil penelitian dapat disimpulkan bahwa proporsi bangsa sapi SimPO tertinggi yaitu 56\%. Umur sapi bakalan yang paling banyak digunakan yaitu sapi dengan gigi poel 1 dan poel 2 . Bobot badan awal sapi $<300 \mathrm{~kg}$ didominasi oleh bangsa sapi PO sedangkan untuk sapi dengan bobot badan awal $>300 \mathrm{~kg}$ didominasi oleh bangsa sapi persilangan yakni SimPO dan LimPO. Nilai BCS sapi yang paling banyak dipilih sebagai bakalan adalah BCS 2-3.

\section{Daftar Pustaka}

Affandhy, L., M.A. Yusran, dan M. Winugroho. 2001. Pengaruh frekuensi pemisahan pedet pra-sapih terhadap tampilan reproduktivitas induk dan pertumbuhan pedet sapi Peranakan Ongole. Prosiding Seminar Nasional Peternakan dan Veteriner. Puslitbangnak. Departemen Pertanian. Bogor.

Carvalho, M.C., Soeparno, dan N. Ngadiyono. 2010. Pertumbuhan dan produksi karkas sapi Peranakan Ongole dan Simental Peranakan Ongole jantan yang dipelihara secara feedlot. Buletin Peternakan 34(1): 38-46.

Dewi, N.W. 2005. Kinerja induk sapi silangan Simmental Peranakan Ongole pada paritas yang berbeda di tingkat peternak. Skripsi. Fakultas Peternakan, Universitas Gadjah Mada, Yogakarta.

Endrawati, E., E. Baliarti, dan S.P.S. Budhi. 2010. Performans induk sapi silangan SimmentalPeranakan Ongole dan induk sapi Peranakan Ongole dengan pakan hijauan dan konsentrat. Buletin Peternakan 34(2): 86-93. 
Musthafa, N.A. 2011. Pengaruh bangsa sapi potong terhadap kinerja reproduksi induk di Kecamatan Cibalong Kabupaten Tasikmalaya, Jawa Barat. Skripsi. Fakultas Peternakan, Universitas Gadjah Mada, Yogyakarta.

Ngadiyono, N. 2007. Beternak Sapi. Citra Aji Pratama. Yogyakarta.

Ontario Farm Animal Council (OFAC). 2010. Body conditioning score of beef cattle. Available at http://www.ofac.org/pdf/body $\% 20$ condition $\% 20$ score.pdf. Accession date: $2^{\text {nd }}$ March 2012.

Rianto, E. dan E. Purbowati. 2010. Panduan Lengkap Sapi Potong. Penebar Swadaya, Anggota IKAPI. Jakarta.

Santosa. 2001. Prospek Agribisnis Penggemukan Pedet. Penebar Swadaya Jakarta.

Sumadi, T. Hartatik, N. Ngadiyono, I.G.S. Budisatria, H. Mulyadi, dan B. Aryadi. 2008. Sebaran populasi sapi potong di Pulau Jawa dan Pulau Sumatera. Kerja Sama APFINDO dengan Fakultas Peternakan, Universitas Gadjah Mada. Yogyakarta.

Thalib, C.H., T. Sugiarti and A. R. Siregar. 1999. Frisian Holstein and their adaptability to the tropical environment in Indonesia. International Training on Strategies for Reducing Heat Stress in Dairy Cattle. Taiwan Livestock Research Institut (Tlri-Coa) August 26 - 31, 2002, Tainan, Taiwan.

Trifena, I.G.S. Budisatria, dan T. Hartatik. 2011. Perubahan fenotip sapi Peranakan Ongole, SimPO dan LimPO pada keturunan pertama dan keturunan kedua (Backcross). Buletin Peternakan 35(1): 11-16.

Widi, T.M., A. Agus, A. Pertiwiningrum, dan T. Yuwanta. 2008. Road Map Pengembangan Ternak Sapi Potong Provinsi D.I. Yogyakarta. Penerbit Ardana Media. Yogyakata.

Widianingtyas, G.N. 2007. Dinamika dan peta distribusi populasi sapi potong di Kecamatan Sentolo Kabupaten Kulon Progo (Studi Kasus). Skripsi Sarjana Peternakan. Fakultas Peternakan, Universitas Gadjah Mada, Yogakarta.

Yulianto, P. dan S. Cahyo. 2010. Pembesaran Sapi Potong Secara Intensif. Penebar Swadaya. Jakarta. 